14 West WHL, Lounsbach GR, Bourgeois C, et al. Biological activity, binding site and affinity of monoclonal antibodies to the fusion protein of respira-

15 Toms GL. Vaccination against respiratory syncytial virus: problems and progress. FEMS Microbiol Immunol 1991; 76: 243-56.

16 Anderson LJ. Strains of respiratory syncytial virus: implications for vaccine development. In: de la Maza LM, Peterson EM, eds. Medical virology 9. New York: Plenum Press, 1990: 187-205.

17 Cane PA, Matthews DA, Pringle CR. Analysis of relatedness of subgroup A respiratory syncytial viruses isolated worldwide. Virus Res 1992; 25: 15-22. $18 \mathrm{Beem} \mathrm{M}$. Repeated infections with respiratory syncytial virus. F Immunol 1967; 98: 1115-22.

19 Robinson BS, Everson JS. Epitopic specificities of human serum antibodies reactive with respiratory synctial virus fusion protein. Arch Virol 1992; 125: $273-86$.

\section{Fragile X syndrome}

The past few years have witnessed dramatic advances in our understanding of the fragile $\mathrm{X}$ syndrome. Clarification of the underlying molecular abnormality at the gene level ${ }^{1}$ has enabled the development of more sensitive and specific diagnostic tests based on Southern blot and polymerase chain reaction technology. ${ }^{2}$ Increasing definition of the associated behavioural phenotype is of potential use diagnostically and therapeutically. ${ }^{3-5}$ Also, specific problems associated with female carrier status are being increasingly recognised. ${ }^{67}$

\section{Epidemiology}

Many paradoxes persist, however, along with ethical dilemmas surrounding the issue of whether or not to undertake presymptomatic screening for an as yet incurable disorder, and if so on which populations this should be undertaken. The condition is certainly common, ${ }^{8}$ although exact prevalence statistics vary considerably. ${ }^{9}$ However, it is still generally acknowledged as the most common inherited cause of learning disabilities affecting between one in 1000 and one in 3000 individuals. Some authorities even speculate that once the proportion of affected individuals who are identified increases, the frequency may even match that of Down's syndrome. ${ }^{10}$

Recent audit of a regional genetic service's pick up of fragile $\mathrm{X}$ cases found a substantial shortfall compared with expected numbers based on reported prevalence rates. ${ }^{11}$ The authors felt that regional variation in prevalence rates was unlikely to be the explanation. Sensitivity problems with the more traditional chromosomal diagnostic analysis may have played a part ${ }^{12}$ but it was concluded that the most likely reason was under-referral of appropriate cases for testing. This view is supported by evidence that clinicians who refer individuals for fragile $\mathrm{X}$ testing with a suspicion based on behavioural features are usually wrong (J Turk, unpublished data). Thus where selection criteria are being used to determine which children to refer to genetic services, they are presumably often inappropriate. This implies that either more children should be tested or that criteria for genetic referral need to be improved.

\section{Genetics}

The fragile $\mathrm{X}$ mental retardation gene (FMR-1) is located at the Xq27.3 'fragile' locus and consists of multiple CGG trinucleotide repeats. ${ }^{1}$ Transgenerational progression from premutation in normal transmitting males and their daughters to full mutation in grandchildren is explained by progressive expansion of the CGG repeat in the $5^{\prime}$ untranslated region of the FMR-1 gene. This expansion
20 Prince GA, Horswood RL, Koenig DW, Chanock RM. Antigenic analysis of a putative new strain of respiratory syncytial virus. $\mathcal{F} \operatorname{Inf} D i s$ 1985; 151: 634-7.

21 Johnson PR, Olmsted RA, Prince GA, et al. Antigenic relatedness between glycoproteins of human respiratory syncytial virus subgroups $A$ and $B$ : evaluation of the contributions of $F$ and $G$ glycoproteins to immunity. f Virol 1987; 61: 3163-6.

22 Hendry RM, Burns JC, Walsh EE, et al. Strain specific serum antibody responses in infants undergoing primary infection with respiratory syncytial virus. F Inf Dis $1988 ; 157,640-7$.

23 Mufson MA, Belshe RB, Orvell C, Norrby E. Subgroup characteristics of respiratory syncytial virus strains recovered from children with two consecutive infections. $\mathcal{F}$ Clin Microbiol 1987; 25: 1535-9.

24 Tristram DA, Welliver RC. Respiratory syncytial virus vaccines: can we improve on nature? Pediatr Ann 1993; 22: 715-8.

produces abnormal DNA hypermethylation and disturbed protein synthesis.

Normal X chromosomes have approximately six to 45 CGG repeats with most clustering around 30 (D Nelson, 8th International Congress of Human Genetics, Washington, 6-11 October 1993). In the general population, $1 \%$ may have a small CGG expansion which represents carrier status and is known as a 'premutation'. These heterozygous premutation carriers have an expansion of between 52 and 200 triplet repeats that is unstable on maternal transmission, with the chance of progression to a full mutation reaching $100 \%$ for women with a premutation of 90 repeats or above. ${ }^{13} 14$ In the full mutation, repeat sequences exceed 200 triplets in size. Normal transmitting males have length increases of about 500 base pairs. Affected males have an increase of between 500 and 5000 base pairs, with hypermethylation of the site. ${ }^{15}$ It should be noted that these figures represent base pairs and not $C G G$ repeats. The reason for this was the use in the study of probes to detect very localised DNA rearrangements that constituted the fragile $\mathrm{X}$ mutations, and whose target was a 550 base pair GC-rich fragment. The insertion size in females may relate to clinical severity but this has yet to be confirmed. ${ }^{15}$ It has also been demonstrated that amplification of the CGG repeat blocks FMR-1 gene transcription, which results in absence of the FMR protein. ${ }^{16}$ Efforts are under way to identify the protein whose production is interfered with by the fragile $\mathrm{X}$ mutation. The protein's function is as yet unknown, although it has been postulated to be of importance in gene regulation. ${ }^{1}$

Fragile $\mathrm{X}$ variants have been identified. These manifest with a similar hypochromic fragile site cytogenetically. However, the molecular abnormality is elsewhere. A common fragile site ${ }^{17}$ is located at Xq27.2 and has been assigned FraX-D to distinguish it from fragile $\mathrm{X}$ syndrome (FraX-A). This site is a potential source of misdiagnosis in female carriers, prenatal testing, and occasional males with very low levels of fragile site expression. ${ }^{18}$ Its prevalence in the general population is unknown, but it is not thought to be associated with mental retardation. High quality banded cytogenetic preparations have confirmed a fragile site distal to the FMR-1 gene, in the proximal portion of $\mathrm{Xq} 28 .{ }^{18}$ This site (FraX-E) is folate sensitive. Cytogenetically it is virtually indistinguishable from FraX-A. The molecular abnormality in FraX-E does appear to expand through generations though perhaps not as consistently as in FraX-A. ${ }^{19}$ Mental retardation is usually mild. Individuals have amplifications of a GCC repeat. ${ }^{20} \mathrm{~A}$ third fragile site, FraX-F, has been identified in Xq27-q28. ${ }^{21}$ Using fluorescent in situ hybridisation (FISH) the site has been shown to lie distal to FraX-A and 
FraX-E. It is folate insensitive and therefore manifests on standard chromosomal culture. The family described showed a lack of association between mental impairment and fragile site expression. The degree of intellectual impairment in affected individuals (all girls) was felt to be unusually severe for fragile X heterozygotes. Furthermore, there were no major behavioural problems or dysmorphic features.

\section{Neurology}

Increasingly research is focusing on the identification of abnormalities that may be mediating between the genetic anomaly and the consequent developmental and behavioural disturbance. Neurophysiological studies suggest a common co-occurrence of fragile $\mathrm{X}$ syndrome and rolandic epilepsy. ${ }^{22}$ Clinically, seizures affect approximately $20 \%$ of males. Epilepsy usually presents in early childhood as staring spells, akinetic episodes, complex partial seizures or generalised tonic-clonic episodes. They are usually infrequent and respond well to standard anticonvulsant medications such as carbamazepine. ${ }^{23}$ More recent research has reported fragile $\mathrm{X}$ individuals with epilepsy as having characteristic brain activity similar to that seen in benign childhood epilepsy with centrotemporal spikes. ${ }^{24}$

Neuropsychological studies have yielded rather contradictory findings with some authors suggesting generalised non-dominant hemispheric dyfunction, ${ }^{25}$ while others propose more localised damage in the dominant hemisphere. ${ }^{26}$ The most exciting reports have been of findings from magnetic resonance imaging. These studies found significantly decreased cerebellar vermis areas, particularly posteriorly, and larger fourth ventricular volumes in fragile $\mathrm{X}$ men $^{27}$ and women ${ }^{28}$ when compared with age and IQ matched controls. Interest has been increased by comparison of the above with earlier observations of small neocerebellar vermal lobules in non-fragile $\mathrm{X}$ autistic individuals. ${ }^{29}$ However, there are several possible explanations for these findings, including small experimental group sizes, nature and degree of mental retardation in fragile $\mathrm{X}$ subjects and coexistence of fragile $\mathrm{X}$ and autism in experimental subjects. Such anatomical abnormalities have not been consistently found in samples of autistic individuals ${ }^{30}$ suggesting that the neuroanatomical abnormality is more likely to be associated with the genetic anomaly (fragile $\mathrm{X}$ ) rather than with a psychiatric syndrome (autism).

\section{Behaviour}

Accumulating evidence confirms that only $2-3 \%$ of autism can be shown to be associated with fragile $\mathrm{X}$ syndrome. ${ }^{31}$ Also there is evidence that the prevalence of autism in fragile X syndrome is no greater than in learning disabled children generally. ${ }^{32}$ Of greater academic and practical interest has been to ask what it is about children with fragile $X$ that reminds us of autism. It seems that nonfragile $\mathrm{X}$ autistic children suffer more social and symbolic disturbance while fragile $X$ children with autistic-like disturbance have more communicatory and ritualistic disorder, in particular in the forms of gaze aversion, delayed echolalia, repetitive speech, and hand flapping. This goes some way to explaining the apparent paradox whereby many fragile $\mathrm{X}$ children fulfil diagnostic criteria for autistic spectrum disorders yet show good ability in, and good awareness of, social interaction.

The possibility of an association between fragile $\mathrm{X}$ and hyperactivity remains contentious with some authors describing major co-occurrences ${ }^{33}$ and others denying any link. ${ }^{34}$ As with the autism debate, the answer may well lie in there being only certain constituent features of hyperactivity (or more broadly speaking attention deficit disorder) that show a specific association. ${ }^{35}$ Teachers, in particular, rate fragile $\mathrm{X}$ boys significantly higher than Down's syndrome boys and boys with idiopathic learning disabilities on the nervous overactivity dimension of the childhood behaviour checklist. In addition they rate them as having more attentional deficits, restlessness, and anxiety. Detailed parental interview confirmed fragile $\mathrm{X}$ boys as more inattentive, restless, and fidgety than both other groups. Activity levels were similar in all groups and declined with increasing developmental ability. However, subjects with fragile $\mathrm{X}$ and Down's syndrome did not show the significant correlations between developmental level and inattentiveness or restlessness noted in subjects with idiopathic learning disability - poor concentration and restlessness in fragile $\mathrm{X}$ boys did not improve with developmental age. This suggests underlying aetiology may have an important bearing on inattentiveness, restlessness, and fidgetiness (fragile $\mathrm{X}$ more, Down's syndrome less) but not overactivity. Aetiology may also influence the developmental progress of these behavioural features, although confirmatory longitudinal studies are required.

\section{Female carriers}

The term 'carrier' is confusing when used in relation to fragile $\mathrm{X}$ syndrome and requires clarification. Females carrying an abnormal expansion of CGG repeats at the site of the FMR-1 gene can be symptomatic or asymptomatic. Symptomatic females have a fragile $\mathrm{X}$ mutation with $\mathrm{CGG}$ repeats exceeding 200 . The clinical severity in this instance probably depends on the relative ratio of inactivated 'healthy' $\mathrm{X}$ chromosomes to fragile $\mathrm{X}$ chromosomes within the central nervous system. Hence females can be asymptomatic yet have the fragile $\mathrm{X}$ mutation with more than 200 CGG repeats provided most of these fragile $X$ chromosomes have been inactivated. These individuals could be called carriers with justification. Alternatively, females can be asymptomatic and have the premutation comprising 52-200 CGG repeats. These individuals could be called carriers as well.

Research reviewed in this section deals mainly with studies of mothers with affected boys where the above three categories could not be distinguished. Hence some variability in findings would be expected. Indeed females heterozygous for fragile $\mathrm{X}$ have been found to display substantial variability in cognitive functioning. However, nonretarded female carriers do often demonstrate the same verbal/performance discrepancy as affected males. They obtain diminished numeracy and visuospatial scores on intelligence testing in the presence of relatively good performance in vocabulary and comprehension. Neuropsychological studies of normal intelligence heterozygote females have also shown significant frontal lobe ('executive function') deficits in cytogenetically expressing individuals. Features include perservation, tangential speech, impulsivity, distractibility, and difficulty with transitions. ${ }^{36}$

Depression has been reported in over $70 \%$ of low expressing fragile $X$ positive women compared with $40 \%$ of control women who have developmentally delayed nonfragile $\mathrm{X}$ children. ${ }^{37}$ Depression is also common in heterozygous women negative for fragile $\mathrm{X}$ who do not have significant cognitive deficits. The relative contributions of the fragile $\mathbf{X}$ gene and environmental stressors are as yet unknown. Thus the subtlest effect of the fragile $\mathrm{X}$ gene may involve personality changes including shyness and a predisposition to anxiety or depression. Now that more fragile $\mathrm{X}$ boys with severer learning disabilities are 
being diagnosed, the onus is on clinicians to identify the more intellectually able, yet emotionally and socially disadvantaged, affected girls.

Further research and replication of the above studies is required utilising the exact number of CGG repeats as well as noting methylation status of the FMR-1 gene and the ratio of inactivated fragile to healthy $\mathrm{X}$ chromosomes.

\section{Intervention}

There is no cure for the fragile $\mathrm{X}$ syndrome but much can be done medically, psychologically, educationally, and socially to maximise potential and minimise handicap. In the classroom compliance and behaviour can be enhanced by awareness of the common gaze aversion, ${ }^{38}$ numeracy and visuospatial difficulties, and sequential information processing problems. ${ }^{39}$ Psychotherapeutic approaches, both behavioural and psychodynamic, have been described as being of potential benefit. ${ }^{40}$ Additionally, there is evidence that the attentional deficits and overactivity often associated with the condition can frequently be helped both by traditional stimulant medications such as methylphenidate ${ }^{41}$ and by folic acid..$^{42} 43$

Department of Mental Health Sciences,

Child and Adolescent Psychiatry Section,

St George's Hospital Medical School,

Cranmer Terrace, London SW17 ORE

Further information including literature for families can be obtained from: The Fragile X Society, 53 Winchelsea Lane, Hastings, East Sussex TN35 4LG (0424 813147).

'Fragile X syndrome: advances and innovations', a multidisciplinary conference, will take place on 15 and 16 June 1995 at St George's Hospital Medical School, University of London. Further information can be obtained from: The Conference Unit, Mental Health Sciences, St George's Hospital Medical School, Cranmer Terrace, London SW17 ORE.

1 Verkerk AJMH, Pieretti M, Sutcliffe JS, et al. Identification of a gene (FMR1) containing a CGG repeat coincident with a breakpoint cluster region exhibiting length variation in fragile X syndrome. Cell 1991; 65: region 14 .

2 Rousseau F, Heitz D, Biancalana V, et al. Direct diagnosis by DNA analysis of the fragile X syndrome of mental retardation. N Engl $f$ Med 1991; 325: of the fragile

3 Turk J. The fragile $\mathrm{X}$ syndrome: on the way to a behavioural phenotype. Br f Psychiatry 1992; 160: 24-35.

4 Turk J. The fragile X syndrome: recent developments. Current Opinion in Psychiatry 1992; 5: 677-82.

5 Turk J, Hagerman RJ, Barnicoat A, McEvoy J. The fragile X syndrome. In: Bouras N, ed. Mental health and mental retardation - recent advances and practices. Cambridge: Cambridge University Press, 1994: 13553.

6 Hagerman RJ, Jackson C, Amiri K, Cronister-Silverman A, O'Connor R, Sobesky W. Girls with fragile $\mathrm{X}$ syndrome: physical and neurocognitive status and outcome. Pediatrics 1992; 89: 395-400.

7 Freund LS, Reiss AL, Hagerman RJ, Vinogradov S. Chromosome fragility and psychopathology in obligate female carriers of the fragile $\mathrm{X}$ chromoand psychopathology in obligate female carrier

8 Webb T, Bundey S, Thake A, Todd J. The frequency of the fragile X chromosome among school children in Coventry. $\mathcal{f}$ Med Genet 1986; 23: 396-9.

9 Hagerman RJ, Silverman AC. Fragile $X$ syndrome: diagnosis, research and treatment. Baltimore: Johns Hopkins University Press, 1991

10 Dykens EM, Hodapp RM, Leckman JF. Prevalence of fragile X syndrome. Behavior and development in fragile $X$ syndrome. Thousand Oaks, London Sage Publications, 1994: 5-6.

11 Barnicoat $A$, Docherty $Z$, Bobrow $M$. Where have all the fragile $\mathrm{X}$ boys gone? Dev Med Child Neurol 1993; 35: 532-9.

12 Wang $Q$, Green E, Barnicoat A, et al. Cytogenetic versus DNA diagnosis in routine referrals for fragile $X$ syndrome. Lancet 1993 ; 342: 1025-6.
13 Yu S, Pritchard M, Kremer E, et al. Fragile X genotype characterised by an unstable region of DNA. Science 1991; 252: 1179-81.

14 Yu S, Mulley J, Loesch D, et al. Fragile-X syndrome: unique genetics of the heritable unstable element. Am f Hum Genet 1992; 50: 968-80.

15 Oberle I, Rousseau F, Heitz D, et al. Instability of a 550-base pair DNA segment and abnormal methylation in fragile X syndrome. Science 1991; 252: $1097-102$.

16 Verheij C, Bakker CE, de Graaff E, et al. Characterisation and localization of the FMR-1 gene product associated with fragile $\mathrm{X}$ syndrome. Nature 1993; 363: 722-4

17 Sutherland GR, Baker E. The common fragile site in band q27 of the human $\mathrm{X}$ chromosome is not coincident with the fragile X. Clin Genet 1990; 37: 167-72

18 Sutherland GR, Baker E. Characterisation of a new rare fragile site easily confused with the fragile X. Human Molecular Genetics 1992; 1: 111-3.

19 Flynn GA, Hirst MC, Knight SJL, et al. Identification of the FRAX-E fragile site in two families ascertained for $\mathrm{X}$ linked mental retardation. $\mathcal{F}$ Med Genet 1993; 30: 97-100.

20 Knight SJL, Flannery AV, Hirst MC, et al. Trinucleotide repeat amplification and hypermethylation of a CpG island in FRAXE mental retardation. Cell 1993; 74: 127-34.

21 Hirst MC, Barnicoat A, Flynn G, et al. The identification of a third fragile site FRAXF, in Xq27-q28 distal to both FRAXA and FRAXE. Human Molecular Genetics 1993; 2: 197-200.

22 Musumeci SA, Colognola RF, Gigli GL, et al. Fragile-X syndrome: a particular epileptogenic EEG pattern. Epilepsia 1988; 29: 41-7.

23 Wisniewski KE, Segan SM, Miezejeski CM, Sersen EA, Rudelli RD. The Fra(X) syndrome: neurological, electrophysiological, and neuropathological abnormalities. Am $\mathcal{F}$ Med Genet 1991; 38: 476-80.

24 Musumeci SA, Ferri R, Elia M, Colognola RM, Bergonzi P, Tassinari CA. Epilepsy and fragile X syndrome: a follow-up study. Am $\mathcal{f}$ Med Genet 1991; 38: 511-3.

25 Crowe SF, Hay DA. Neuropsychological dimensions of the fragile $X$ syndrome: support for a non-dominant hemisphere dysfunction hypothesis. Neuropsychologia 1990; 28: 9-16.

26 Grigsby JP, Kemper MB, Hagerman RJ. Developmental Gerstmann syndrome without aphasia in fragile X syndrome. Neuropsychologia 1987; 25: 881-91.

27 Reiss AL, Aylward E, Freund LS, Joshi PK, Bryan RN. Neuroanatomy of fragile X syndrome: the posterior fossa. Ann Neurol 1991; 29: 26-32.

28 Reiss AL, Freund L, Tseng JE, Joshi PK. Neuroanatomy in fragile X females: the posterior fossa. Am f Hum Genet 1991; 49: 279-88.

29 Courchesne E, Yeung-Courchesne R, Press GA, Hesselink JR, Jernigan TL. Hypoplasia of cerebellar vermal lobules VI and VII in autism. $N$ Engl $f$ Med 1988; 318: 1349-54.

30 Garber HJ, Ritvo ER, Chiu LC, et al. A magnetic resonance imaging study of autism. Normal fourth ventricle size and absence of pathology. $A m \mathcal{F}$ Psychiatry 1988; 146: 532-4.

31 Bailey A, Bolton P, Butler L, et al. Prevalence of the fragile $\mathrm{X}$ anomaly amongst autistic twins and singletons. $\mathcal{F}$ Child Psychol Psychiatry 1993; 34: 673-88.

32 Turk J. Behavioural characteristics of children with fragile $\mathrm{X}$ syndrome. Psychiatric Genetics 1991; 2: 98.

33 Hagerman RJ. Fragile X syndrome. Current Problems in Pediatrics 1987; 17: 627-74.

34 Einfeld $\mathrm{S}$, Hall W, Levy $\mathrm{F}$. Hyperactivity and the fragile $\mathrm{X}$ syndrome. f Abnorm Child Psychol 1991; 19: 253-62.

35 Turk J. Attentional deficits in boys with fragile $\mathrm{X}$ syndrome: evidence for a characteristic developmental profile. Proceedings of the British Paediatric Association Annual Meeting. University of Warwick. London: BPA, 1994.

36 Mazzocco M, Hagerman $R$, Cronister-Silverrman A, Pennington B. Specific frontal lobe deficits among women with the fragile $\mathrm{X}$ gene. $\mathcal{F} \mathrm{Am}$ Acad Child Adolesc Psychiatry 1992; 31: 1141-8.

37 Mandel J-L, Hagerman R, Froster U, et al. Fifth international workshop on the fragile X and X-linked mental retardation. Am $\mathcal{F}$ Med Genet 1992; 43: 5-27.

38 Wolff PH, Gardner J, Paccia J, Lappen J. The greeting behavior of fragile X males. Am f Ment Retard 1989; 93: 406-11.

39 Dykens EM, Hodapp RM, Leckman JF. Strengths and weaknesses in the intellectual functioning of males with fragile $\mathrm{X}$ syndrome. American fournal of Mental Deficiency 1987; 92: 234-6.

40 Brown JR, Braden M, Sobesky W. The treatment of behavioral and emotional problems. In: Hagerman RJ, Cronister-Silverman A, eds. Fragile $X$
syndrome: diagnosis, treatment and research. Baltimore: Johns Hopkins syndrome: diagnosis, treatment
University Press, 1991: 311-26.

41 Hagerman RJ, Murphy MA, Wittenberger MD. A controlled trial of stimulant medication in children with the fragile $\mathrm{X}$ syndrome. Am $\mathcal{F}$ Med Genet 1988; 30: 377-92

42 Hagerman RJ, Jackson AW, Levitas A, et al. Oral folic acid versus placebo in the treatment of males with the fragile X syndrome. Am $\mathcal{F}$ Med Genet 1986; 23: $241-62$.

43 Turk J. Fragile X syndrome and folic acid. In: Hagerman RJ, McKenzie P, eds. 1992 International Fragile X Conference Proceedings. Dillon, Colorado: Spectra Publishing, 1992: 195-200. 